【論

文】

\title{
単一孔から発生する気泡群による酸素移動特性 \\ EXPERIMENTAL STUDIES ON THE OXYGEN TRANSFER CHARACTERISTICS OF AIR BUBBLES FROM A SINGLE ORIFICE
}

\author{
松 本 順一 郎* - 中 村 玄 正** \\ By Junichiro MATSUMOTO and Michimasa NAKAMURA
}

\section{1.はじめに}

エアレーションタンクにおける酸素の移動を考えると き, 実用的観点に基づいた研究としては, 実際規模もし くはパイロットプラント規模の装置を用いて，形状，容 積, 水深, 散気板面積, 空気流量等と酸素吸収効率の関 係を指数式で表わそうとする King ${ }^{1)}$ や柏谷ら ${ }^{2)}$ の研究, また, 散気装置の種類や位置等について酸素吸収効率と の関係を示した Bewtra ら ${ }^{3)}$ や寺岡ら ${ }^{4)}$ 研究, さらに, 模型旋回流式エアレーションタンクのスケールアップを 検討した宗宮ら ${ }^{5}$ の研究がある. これらの研究は, 現象 を支配する因子を装置特性の点から検討したもので，エ アレーション操作や設計上, きわめて重要な方向である と考えられる.

一方, これら各種装置特性の間に内在する普偏性を追 求し, エアレーションの問題を気泡の性状や挙動から明 らかにし，酸素の移動や液（水）の擋拌に結びつけてい く方向がある.このような考え方に基づいた研究として は, Pasveer ${ }^{6)}$, Banhart ${ }^{7)}$, Suschka ${ }^{8)}$ のように, 総括容量 係数 $K_{L} a$ から液側物質移動係数 (液境膜係数) $k_{L}$ を分 離しようとする研究がある.これらの研究は, エアレー ションの基本因子である液境膜係数 $k_{L}$ と気液接触界面 面積 $a_{V}$ をこれに関与する種々の因子との関連づけによ って解明しようとするものである.

本報告は, すでに明らかになっている気泡発生孔径と 空気流量, 気泡径分布, 気泡の形状や挙動等の知見 ${ }^{9)}$ 基礎とし, 気泡群のガスホールドアップ, 気液接触界面 面積, 総括容量係数, 液境膜係数, さらに, 気泡生成時 や破裂時等の端効果における酸素移動等の関連性を実験 的に検討することによって，単一孔から発生する気泡か らの酸素移動特性に関する基礎的知見を得ることを目的

\footnotetext{
* 正会員 工博 東北大学教授 工学部土木工学科

** 正会員 工博 日本大学助教授 工学部土木工学科
}

とし, 考察を進めているものである.

\section{2. 実験装置および実験方法}

図一1 に実験装置の概略を示している. 実験に使用し ているエアレーションカラムは, 内径 $140 \mathrm{~mm}$, 高さ $1200 \mathrm{~mm}$ のパイレックスガラス製円筒で, 蒸留水を満 たしている. カラムの外側には内のり $300 \times 300 \times 1300$ $\mathrm{mm}$ の両面ガラス製角型水槽 $\mathrm{G}$ を設け, カラム内に存在 する気泡を撮影する際のレンズ効果によるひずみを最小 限に抑え, また, カラム内の水温を一定 $\left(18.0 \sim 23.5^{\circ} \mathrm{C}\right)$ に保つ恒温槽の役を果たしている.

所定の空気流量が得られるようにニードルバルブを調

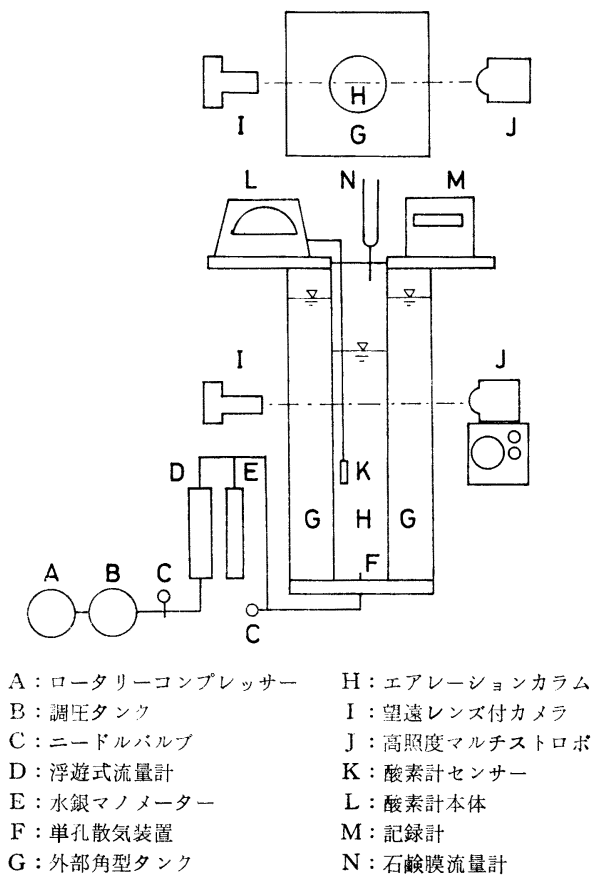

図一1実験装置 
整し, カラム内に蒸留水を注入する. その後, 石喃膜流量計とニードルバルブによって空気流 量を微調整する。ついで, 窒素ガスをカラム底 の散気装置から送り込み, 水中の溶存酸素を放 散させ, 溶存酸素が $1.0 \mathrm{mg} / \mathrm{l}$ 以下になったと ころで窒素ガスの送気を停止すると同時に, 溶 存酸素の連続記録を開始する. ロータリーコン プレッサーから送られる空気は, 調圧室で整圧 され, ニードルバルブを経て単一孔気泡発生装 置に導玑，気泡となってカラム内の水中に放 出される. 発生する気泡から水中に溶解する酸 素の量注1) は, 溶存酸素分析計注2) (B社 777 型) と高感度記録計 ( $\mathrm{T}$ 社 EPR-2 TD) によって

実験条件

\begin{tabular}{|c|c|c|c|c|c|}
\hline $\begin{array}{l}\text { 実験 } \\
\text { No. }\end{array}$ & $\begin{array}{c}\text { 気泡発生 } \\
\text { 孔楅 } \\
\delta(\mathrm{cm})\end{array}$ & $\begin{array}{c}\text { 空気 流量 } \\
G_{s}\left(\mathrm{~cm}^{3} / \mathrm{sec}\right)\end{array}$ & $\begin{array}{c}\text { 孔での空気速度 } \\
u_{G}(\mathrm{~cm} / \mathrm{sec})\end{array}$ & $\begin{array}{l}\text { 孔での空気の } \\
V 1, \text { ズ数 } \\
R_{e G}(-)\end{array}$ & $\begin{array}{l}\text { ガス(気泡)の } \\
\text { 空 塔 速 度 } \\
u_{g} T(\mathrm{~cm} / \mathrm{sec})\end{array}$ \\
\hline A & 0.010 & $0.158 \sim 1.657$ & $2020 \sim 21100$ & $148 \sim 789$ & $0.00103 \sim 0.01076$ \\
\hline $\mathrm{B}$ & 0.020 & $0.423 \sim 4.802$ & $1350 \sim 15280$ & $197 \sim 2485$ & $0.00275 \sim 0.03120$ \\
\hline $\mathrm{C}$ & 0.031 & $0.576 \sim 14.84$ & $810 \sim 20990$ & $178 \sim 3882$ & $0.00374 \sim 0.09640$ \\
\hline D & 0.060 & $0.430 \sim 18.00$ & $152 \sim 5370$ & $67 \sim 2872$ & $0.00279 \sim 0.1169$ \\
\hline $\mathrm{E}$ & 0.089 & $0.413 \sim 15.96$ & $82 \sim 3170$ & $54 \sim 2116$ & $0.00268 \sim 0.1037$ \\
\hline $\mathrm{F}$ & 0.120 & $1.82 \sim 19.78$ & $161 \sim 1750$ & $141 \sim 1543$ & $0.01180 \sim 0.1285$ \\
\hline
\end{tabular}

蒸留水の物理的性質 ${ }^{10}$ )
水 温: $t$
密 度 : $\rho_{L} \quad 0.999 \sim 0.998\left(\mathrm{~g} / \mathrm{cm}^{3}\right)$
粘 性 係 数: $\mu_{L} \quad 1.06 \times 10^{-2} \sim 0.960 \times 10^{-2}(\mathrm{~g} / \mathrm{cm} \cdot \mathrm{sec})$
動 粘 性 係数: $\nu_{L} \quad 1.06 \times 10^{-2} \sim 0.962 \times 10^{-2}\left(\mathrm{~cm}^{2} / \mathrm{sec}\right)$
表面張力: $\sigma_{L} \quad 73.1 \sim 72.4(\mathrm{dyn} / \mathrm{cm})$
酸素の抎散係数 : $D_{L} \quad 1.90 \times 10^{-5} \sim 2.16 \times 10^{-5}\left(\mathrm{~cm}^{2} / \mathrm{sec}\right)$

連続的に記録し, 時間-濃度曲線から, 総括容量係数 $K_{L} a$ を求めている，気泡の形状や大きさ，上昇速度等は高照 度マルチストロボ (S 社 PS-240) を光源とし，これと連 動する望遠レンズ付カメラによって, カラム内の気泡を 写真撮影し，得られたフィルムをスクリーン上に桩大投 影してノギスを用いて長径, 短径, 移動距離を測定して 求めている. 一方, 気泡のホールドアップ $h_{\varepsilon}$ は, 写真 撮影によって得られたフィルムのカラムにおける単位容 積中の気泡の個数 $n_{B}$ と気泡体積 $v_{B}$ 注 3 ) の積の総和から

$$
h_{s}=\frac{\sum n_{B} \cdot v_{B}}{V_{T}}
$$

として求めた. 同様に気泡の気液接触界面面積 $A_{B}$ は単 位深さ $z$ 中の気泡の個数 $n_{B}$ と気泡表面積 $s_{B}$ の積の 総和から

$$
A_{B}=\frac{\sum n_{B} \cdot s_{B}}{z} \cdot z_{H} \ldots \ldots \ldots \ldots \ldots \ldots \ldots \ldots(2)
$$

として求めた. 写真一1 は測定フィルムの一例であり,

注 1）溶存酸素に対する水深の影響

溶存酸素が水深によって影響されることについて, Oldshue ${ }^{10)}$ は補正式として次式を与えている。

$$
C_{s}=C_{w s}\left(\frac{\text { 気泡中酸素濃度 }(\%)}{42(\%)}+\frac{\text { タンク底圧力 }(\mathrm{mAq} .)}{2 \times 10.34(\mathrm{mAq} .)}\right)
$$

筆者らは，溶存酸素計センサーをエアレーションカラムのほ ぼ中間位置 (水面下約 $40 \mathrm{~cm}$ ) に設置し，ウィンクラー法と対照 しながらエアレーションし，大気圧下における飽和溶存酸素值 $C_{w s}$ と比較する予備実験を行った．その結果， $C_{w s}$ に対する $C_{s}$ の比 $\frac{C_{s}}{C_{w s}}=1.01 \sim 1.05$ となり, 水深変化による溶存酸素濃度に ついては，上記の補正式がほぼ適用できることを確認した。

注 2) 溶存酸素計の感度

ポーラログラフ式酸素分析計においては，センサー先端に挍 いて, テフロン膜での酸素の抬散を行うため, 流速付与が必要 である. 本研究に用いた分析計もまた, 公称で最小流速 $30 \mathrm{~cm} /$ sec が必要とされていたが, $15 \mathrm{~cm} / \mathrm{sec}$ 程度の流速が与えられれ ば, 再現性はきわめて良好であった。しかし，本研究において 空気量がきわめて小さい場合 $\left(G_{s}=1.5 \mathrm{~cm}^{3} / \mathrm{sec}\right.$ 以下) には液流 速が $15 \mathrm{~cm} / \mathrm{sec}$ 以下であったため, 空気量に応じて, ウィンクラ 一法と対応させつつ，検量範囲を 3 段階に分けて 溶存酸素計に 対する補正を試みた。

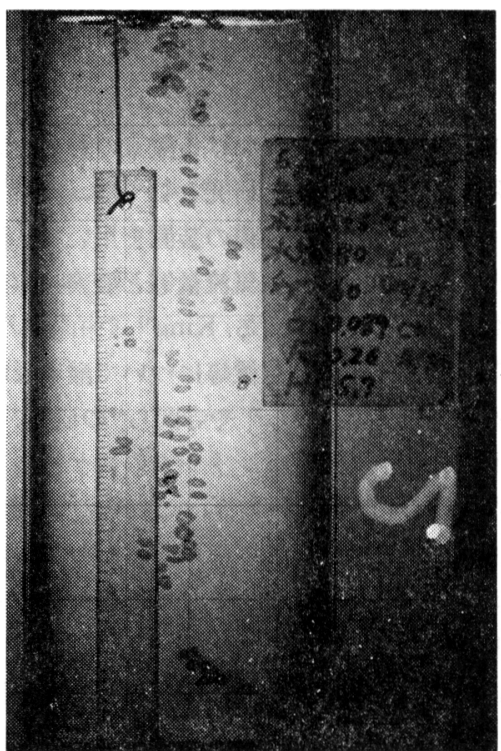

写真一1 撮影フィルムの一例

図一2 は, 長径 $D_{a}$, 短径 $D_{b}$, 上昇速度 $u_{b}$ の测定法を モデル的に示したものである. ストロボ発光回数は， $3000 \mathrm{rpm}$ である. 実験条件 ${ }^{11}$ を表一1 に示す.

\section{注 3）気泡径に及ぼす水深の影響}

実験時における最大水深 $1.2 \mathrm{~m}$ における圧力を $P_{1}$, そのとき の気泡体積を $v_{B 1}$, 水面付近に打ける圧力を $P_{2}$, そのときの気 泡体積を $v_{B 2}$ とすると, 次式が成立する。

$$
\begin{array}{r}
P_{1} \cdot v_{B 1}=P_{2} \cdot v_{B 2} \ldots \ldots \ldots \ldots \ldots \ldots \ldots \\
P_{1}=11.54 \mathrm{mAq}, P_{2}=10.34 \mathrm{mAq} \text { より }
\end{array}
$$

$$
v_{B 2}=\frac{P_{1}}{P_{2}} \cdot v_{B 1}=\frac{11.54}{10.34} v_{B 1}=1.116 v_{B 1}
$$

これを気泡径の変化とすると

$$
\frac{\pi}{6} D_{v 2}{ }^{3}=1.116 \cdot \frac{\pi}{6} D_{v 1}{ }^{3} .
$$

$\therefore D_{v_{2}}=\sqrt[3]{1.116} \cdot D_{v_{1}}=1.037 \cdot D_{v_{1}} \fallingdotseq 1.04 \cdot D_{v_{1}} \cdots \cdots$ (A.5) したがって, カラム底より水面に至ると, 気泡径で約 $4 \%$ の増 加となる. 一方, 気泡上昇中に打㵊大 $10 \%$ 程度の酸素の水 一の溶解による気泡体積の減少による 相殺, 上昇中の形状変化 等を考慮すると, 気泡径に及ぼす水深の影響はほぼ無視可能で あろら。 


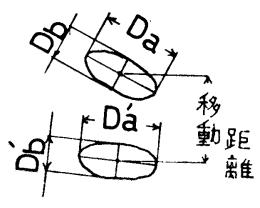

図一2 気泡長径, 短径, 移動距離の測定法

\section{3. 実験結果と考察}

\section{（1）気泡のホールドアップ，空塔速度および気泡群 の平均上昇速度}

エアレーションタンク内に発生された気泡は, タンク 内を上昇し, 自由水面に到達したのち, 破裂・消隇す る. 連続的に空気が散気装置よりタンク内に気泡として 発生している場合には, 気泡の水中における上昇速度が ほぼ一定であるとすれば, タンク内には常に一定量の空 気が気泡となって存在し, また, 気泡からタンク内の水 に供給される酸素は, 気泡が水中を上昇する間に移動す ると考えられ, タンク内に存在する気泡の量, すなわち, 気泡のホールドアップによって大きく支配されよう.

気泡のホールドアップ $h_{\varepsilon}$ は, 気泡の上昇速度 $u_{b}$, 水 深 (気液混相時) $z_{H}$, 気泡の全存在個数 $N_{B}$, 気泡の体 積 $v_{B}$, カラム断面積 $A_{T}$, 空気流量 $G_{s}$ 等との間で, 次 のように考えることができる.

ある気泡が上昇速度 $u_{b}$ で水深 $z_{H}$ なる距離を上昇す るのに要する時間 $\tau_{\theta}$ は, 次式で与えられる.

$$
\tau_{\theta}=\frac{z_{H}}{u_{b}}
$$

また, カラム内に発生する単位時間当りの気泡の個数 $n_{B t}$ は,

$$
n_{B t}=\frac{G_{s}}{\bar{v}_{B}}
$$

であり,カラム内に滞留する気泡の総個数 $N_{B}$ は,

$$
N_{B}=n_{B t} \cdot \frac{z_{H}}{\bar{u}_{b}}=\frac{G_{s}}{\bar{v}_{B}} \cdot \frac{z_{H}}{\bar{u}_{b}}
$$

となり, カラム内に存在する気泡の総体積 $V_{B}$ は,

$$
V_{B}=\sum_{i=1}^{N} v_{B i}=N_{B} \cdot \bar{v}_{B}=\frac{G_{s} \cdot z_{H}}{\bar{u}_{B}}
$$

となる. 以上の関係から, 気泡のホールドアップ $h_{\varepsilon}$ と ガス空塔速度 $u_{g T}$, 気泡群の平均上昇速度 $\bar{u}_{b}$ との間に は,

$$
\begin{aligned}
h_{\varepsilon} & =\frac{V_{B}}{V_{T}}=\frac{\sum n_{B} \cdot v_{B}}{V_{T}}=\frac{G_{s} \cdot z_{H}}{\bar{u}_{b}} \cdot \frac{1}{z_{H} \cdot A_{T}} \\
& =\frac{G_{s}}{A_{T}} \cdot \frac{1}{\bar{u}_{b}}=\frac{u_{g T}}{\bar{u}_{b}} \ldots \ldots \ldots \ldots \ldots \ldots \ldots \ldots \ldots \ldots \ldots \ldots \ldots \ldots \ldots
\end{aligned}
$$

が成立する.

気泡に関するホールドアップと空塔速度, 気泡群の平 均上昇速度についての研究は, 化学工学の分野において
多くの研究がなされているが，その工学的必要性から， 散気装置としては多孔板・多孔質板を用い, 空気と液に ついては, 気液並流・向流について研究されたものが多 い. 吉田ら ${ }^{13)}$ は, カラム径 $7.7 \sim 60 \mathrm{~cm}$ の範囲の気泡塔 で, 空気一水系および空気- $\mathrm{Na}_{2} \mathrm{SO}_{3}$ 水溶液系において, $0.22 \sim 4.0 \mathrm{~cm}$ 径の単孔ノズルを用いて実験を行い, 気 泡のホールドアップ $h_{\varepsilon}$ を空塔速度 $u_{g T}$ との関係で示 している.それによれば， $u_{g T}$ が $2.78 \mathrm{~cm} / \mathrm{sec}$ 以下であ れば, $h_{\varepsilon}$ は $u_{g T}$ の 0.875 乗に比例して大きくなり， $u_{g T}$ が $2.78 \mathrm{~cm} / \mathrm{sec}$ 以上になると気泡相互の干渉や合 体, 液の乱れによって, $h_{\varepsilon}$ の $u_{g} T$ に対する増加率は小

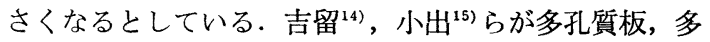
孔板, 単孔ノズル等を用いた気液向流・並流で行った実 験でも, 吉田らの結果と同様な報告がなされている.こ れらの研究は, 気泡擋乱遷移領域 $\left(u_{g T}=2 \sim 5 \mathrm{~cm} / \mathrm{sec}\right.$ 以 上）と考えられる範囲を中心としたものであって, 発生 気泡の合体・分裂が激しくなり, 不規則な形状の大小気 泡が群上昇し, タンク頂部においては気泡累積層を生じ ている. そのため, 上昇速度として個々の気泡について 求めることはきわめて困難であり, 式 (7) に基づいて, 測定した気泡のホールドアップと空塔速度から気泡群の 平均上昇速度を算定し, 気液接触界面面積を明らかにす るための滞留時間を推定しようとするものである.

一方, 実際のエアレーションタンクにおける空塔速度 は, エアレーションの目的が活性污泥フロックへの酸素 供給のバランスや混合擋拌さらに沈降防止を目的として いることから, 同じ気泡群による流動ではあっても, 非 生物系を扱う前述の化学工学の分野における空塔速度の 研究範囲よりもかなり小さく, 気泡流動層としての性状 に大きな相違がある.このよらな, エアレーションタン ク内における空塔速度の小さい範囲におけるガスホール ドアップ $h_{\varepsilon}$ と空塔速度 $u_{g T}$ について,

$$
h_{\varepsilon}=0.014 u_{g} T^{0.80}
$$

を得た (図一3).

一方, 既報 ${ }^{9}$ において, 筆者らは気泡群の平均上昇速 度 $\bar{u}_{b}$ と空塔速度 $u_{g T}$ について, 気泡発生孔径 $\delta$ をパ ラメーターとした実験式を示した.

$$
\bar{u}_{b}=68.2 \delta^{0.15} u_{g} T^{0.10}
$$

本式を, 大型エアレーションタンクを用いて気泡や液の 挙動・酸素移動等を実測した柏谷ら 22 の実験結果に適用 して, 表一2 のような結果を得た. なお, 柏谷らの空塔 速度を求める場合の基準断面積は, 散気板面積 $0.9 \mathrm{~m}^{2}$ (散気板面積比 10\%)，1.2 $\mathrm{m}^{2}$ (同 15\%) を用い，また， 気泡発生孔径 $\delta$ は, 使用したのがセラミック散気板であ ることや発生気泡の分布から推測して, $0.01 \sim 0.1 \mathrm{~cm} の$ 範囲であるとした. もちろん, 筆者らの装置と柏谷らの 装置はまったく異なるものであるが, エアレーション時 


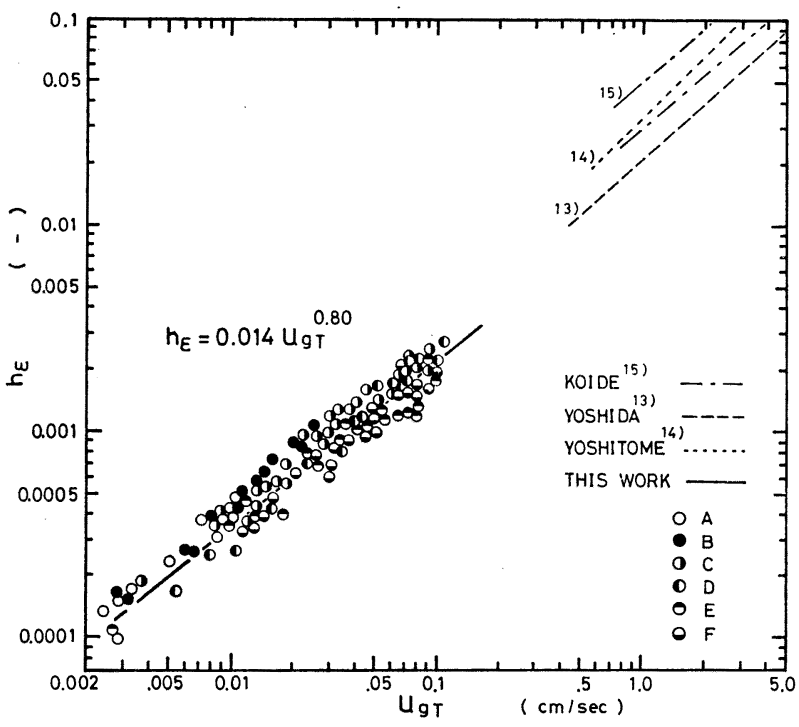

図一3空塔速度と気泡のホールドアップ

表一2 空塔速度による気泡上昇速度の推定 (柏谷ら ${ }^{2)}$ の結果との比較)

\begin{tabular}{|c|c|c|c|c|}
\hline & \multirow{2}{*}{$\begin{array}{c}\text { 空気流量 } \\
G_{s} \\
\left(l / \mathrm{m}^{3} \cdot \min \right)\end{array}$} & \multirow{2}{*}{$\begin{array}{c}\text { 空塔速度 } \\
U_{g T} \\
(\mathrm{~cm} / \mathrm{sec})\end{array}$} & \multicolumn{2}{|c|}{ 気泡上昇速度 } \\
\hline & & & $\begin{array}{c}\bar{u}_{b} \text { (実洌) } \\
(\mathrm{cm} / \mathrm{sec})\end{array}$ & $\begin{array}{c}\bar{u}_{b}=42.0 U_{g} T^{0.10} \\
\quad(\mathrm{~cm} / \mathrm{sec})\end{array}$ \\
\hline & 9 & 0.672 & $42 \sim 44$ & 40.7 \\
\hline 散気板面積比 & 18 & 1.34 & $42 \sim 45$ & 43.7 \\
\hline \multirow[t]{2}{*}{$10 \%$} & 27 & 2.01 & $45 \sim 50$ & 45.5 \\
\hline & 35 & 2.61 & - & 46.7 \\
\hline \multirow{4}{*}{$\begin{array}{c}\text { 散気板面積比 } \\
15 \%\end{array}$} & 9 & 0.504 & $28 \sim 34$ & 39.6 \\
\hline & 18 & 1.01 & $34 \sim 38$ & 42.4 \\
\hline & 27 & 1.51 & $33 \sim 36$ & 44.2 \\
\hline & 35 & 1.96 & $39 \sim 46$ & 45.4 \\
\hline
\end{tabular}

における気泡群の平均上昇速度を空塔速度から推定する ことができよう。

次に, 式 (9) を発生孔径 $\delta=0.01 \sim 0.12 \mathrm{~cm}$ の範囲の ものについてまとめると, 気泡群の平均上昇速度 $\bar{u}_{b}$ は 空塔速度 $u_{g T}$ の関数として,

$$
\bar{u}_{b}=42.4 u_{g T^{0.10}}
$$

を得る.

なお, 式 (7) に基づいて, ホールドアップと空塔速度 から気泡群の平均上昇速度を求める場合と, 写真撮影に よって直接, 気泡群の平均上昇速度を求めた場合とで は, 測定の際の誤差の結果, 多少の相違があり, 後者の 方が, 気泡群の平均上昇速度はやや小さめの評価となっ ている. 本研究においては, 直接空塔速度から平均上昇 速度を推定する式 (9) または式 (10) を用いて, 結果の 整理を行った.

\section{（2）カラム内における気液接触界面面積}

気泡の存在しているカラム内の気液接触界面面積 $a_{V}$

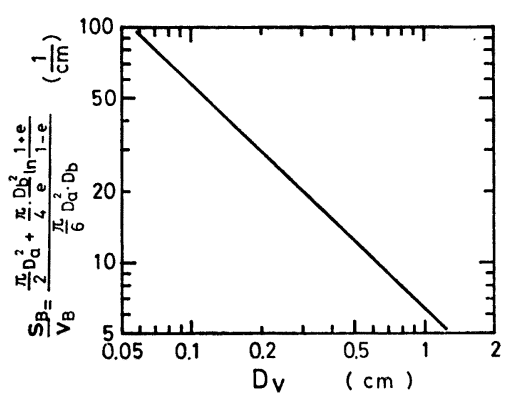

図一4気泡径と気泡表面積の体積に対する比

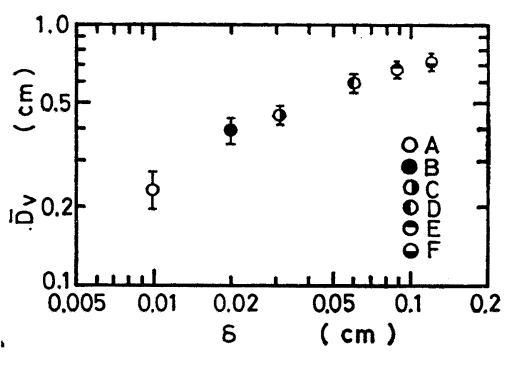

図一5 気泡発生孔径と発生気泡径

は, 気液混相単位容積当りの気泡の占める全表面積とし $\tau$,

$$
a_{V}=\frac{A_{B}}{V_{T}}=\frac{\sum n_{B} \cdot s_{B}}{V_{T}}
$$

で示される.

前項で考察しているように，一般に空気の空塔速度に 比例して, 気泡のホールドアップは増加する. また, 図 -4 に示されるように, 気泡径 $D_{v}$ が小さくなればなる ほど, 気泡の体積当りの表面積 $s_{B} / v_{B}$ は増加する.さ らに実験の範囲内では, 平均発生気泡径 $\bar{D}_{\boldsymbol{v}}$ は, 既報の ように流速因子数 $N_{W}\left(=W_{e} \cdot F_{r}{ }^{-1 / 2}\right)$ の関数 $\left.{ }^{9}\right)$ として示 されるが，これを概略の傾向として示すと，図一5に見 られるように,ほぼ気泡発生孔径 $\delta に$ 対応した大きさで ある.したがって, 一般に空塔速度 $u_{g T}$ が大きくなる とガスホールドアップ $h_{\varepsilon}$ が増加し, 接触界面面積は増 加し, また, 気泡発生孔径 $\delta$ が小さくなるほど, 発生気 泡径 $D_{v}$ は小さくなり，接触界面面積は増加する．これ らの関係を次のように示すことができる.

$$
\begin{aligned}
a_{V} & =\frac{A_{B}}{V_{T}}=\frac{1}{V_{T}} \cdot \frac{V_{B}}{\frac{\pi}{6} \cdot k_{v} \cdot \bar{D}_{v}{ }^{3}} \cdot \pi \cdot k_{s} \cdot D_{v}{ }^{2} \\
& =\frac{h_{\varepsilon} \cdot V_{T}}{V_{T}} \frac{6 \cdot k_{s}}{k_{v}} \frac{1}{\bar{D}_{v}}=h_{\varepsilon} \cdot \frac{6 \phi_{s}}{D_{v}}=f\left(u_{g T}, \delta\right)
\end{aligned}
$$

図一6 は, 空塔速度 $u_{g} T$ に対し, 発生孔径 $\delta$ をパラ メーターとして, 写真撮影法で求めた気泡の長径 $D_{a}$, 短径 $D_{b}$ より, 回転楕円体として表面積 $s_{B}$ と個数か ら, カラム内における気泡の接触界面面積 $a_{V}$ を点緅し 


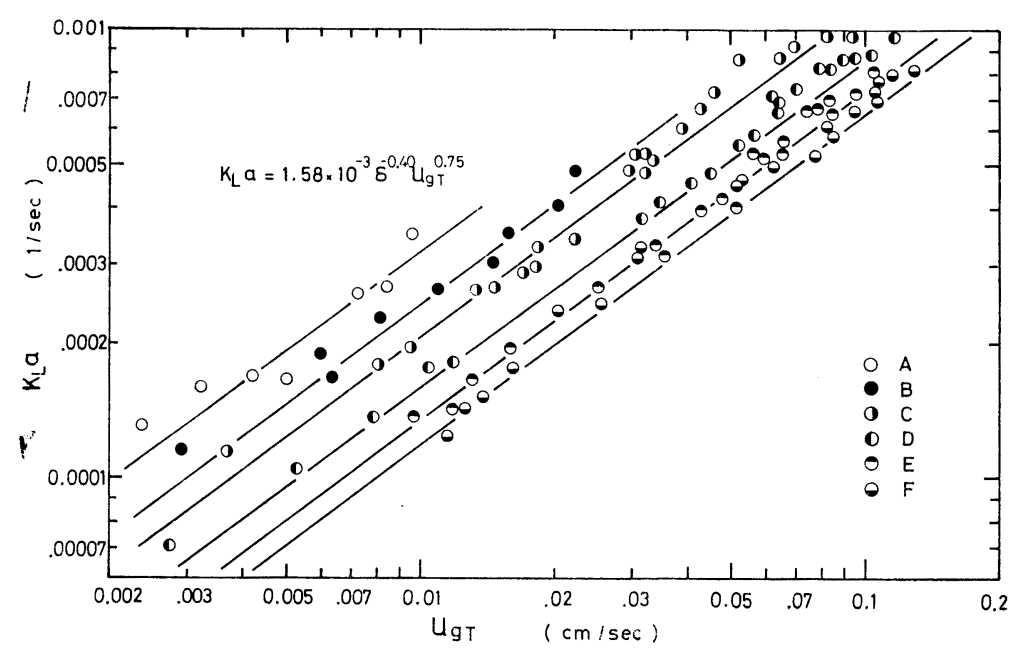

図一6 空塔速度と気液接触界面面積の関係
$K_{L} a_{(20)}=K_{L} a_{(t)} \cdot 1.024^{20-t}$

により補正している.

図一7 は, 空気流量 $G_{s}$ に対 し, 溶存酸素の時間-濃度曲線 （式(16)）から求めた総括容量 係数 $K_{L} a$ を点緅したものであ り, 気泡発生孔径 $\delta$ や空気流量 $G_{s}$ によって $K_{L} a$ が変化して いることがわかる.

そこで, カラム断面積当りの 空気流量, すなわち, 空塔速度 $u_{g T}$ に対し総括容量係数 $K_{L} a$ を整理したものが 図一8であ り, $u_{g T}$ の増加とともに $K_{L} a$ が増加していることがわかる.
たものであり, 空塔速度 $u_{g T}$ の増加や気泡発生孔径 $\delta$ の減少に伴って, 界面面積 $a_{V}$ の増大が顕著であり, 実 験結果に適合するように整理して

$$
a_{V}=0.0248 u_{g T^{0.72}} \cdot \delta^{-0.50} \ldots
$$

を得た。

只木ら ${ }^{16)}$ は, 空塔速度 $u_{g T}$ が $1 \sim 10 \mathrm{~cm} / \mathrm{sec}$ の範囲で 気泡の接触界面面積 $a_{V}$ を求め, $u_{g T}$ が $5 \mathrm{~cm} / \mathrm{sec}$ 付近 までは, $a_{V}$ は $u_{g T}$ とともに直線的に増加し， $u_{g T}$ が これより大となると，気泡の合体現象等の相互干涉によ って, 気泡のホールドァップが空塔速度に比例しなくな り，界面面積の増加率が幾分減少することを指摘してい

る. 筆者らの実験の場合, 空塔速度 $u_{g} T$ は $0.002 \sim 0.1$ $\mathrm{cm} / \mathrm{sec}$ の気泡流動層としての範囲であり, 気泡の合体 現象等はあまりみられていない.

\section{（3）総括容量係数 $\boldsymbol{K}_{L} \boldsymbol{a}$}

エアレーション系内全体について, 気泡の界面を通し て液中に移動する酸素の吸収速度 $N_{\mathrm{O}_{2}}$ は, 気泡の界面 面積 $A_{B}$ と濃度推進力 $\Delta c=c_{s}-c$ に比例し, 次式で示 される。

$$
N_{\mathrm{O}_{2}}=\frac{d W_{\mathrm{O}_{2}}}{d \tau}=K_{L} \cdot A_{B}\left(c_{s}-c\right) \cdots \cdots(14)
$$

さらに, カラム容積 $V_{T}$ 当りの気液接触界面面積 を $a_{V}\left(=A_{B} / V_{T}\right)$ であらわせば,

$$
\frac{1}{V_{T}} \cdot \frac{d W_{\mathrm{O}_{2}}}{d \tau}=\frac{d c}{d \tau}=K_{L} a\left(c_{s}-c\right) .
$$

より, $t=0$ で $c=0$ の初期条件を考慮して, 総括 容量係数 $K_{L} a$ は,

$$
K_{L} a=\frac{1}{\tau} \ln \frac{c_{s}}{c_{s}-c}
$$

により求められる. また，水温の影響について は, 基準温度を $20^{\circ} \mathrm{C}$ として ${ }^{17)}$,
また, 気泡発生孔から発生する気泡の大きさは, 気泡発 生孔径と空気流量に関係し, 発生孔径 $\delta$ が小さいほど気 泡径 $\bar{D}_{v}$ は小さくなり, 気泡体積当りの接触界面面積が 大きくなることから, 同一空塔速度であっても, 発生孔 径 $\delta$ が小さいほど, 総括容量係数 $K_{L} a$ は大きくなって いる.

以上の結果から, 実験結果を整理して, 総括容量係数 $K_{L} a$ と空塔速度 $u_{g T}$ および発生孔径 $\delta$ の間について,

$$
K_{L} a=1.58 \times 10^{-3} \cdot \delta^{-0.40} \cdot u_{g} T^{0.75}
$$

なる実験式を得た.

\section{（4）端効果について}

気泡エアレーションにおいては，発生孔における気泡 の生成時, 水面到達後の破裂時, ならびに, 自由水面を 通じての酸素の移動が端効果として酸素の移動に関係し てくる.

Johnson $^{18)}$ らは，気泡塔の高さを変化させて端効果の 大きさを求め, 気泡塔での端効果溚高相当に換算して $6 \mathrm{~cm}$ 程度であってそれほど大きいものではない, と述

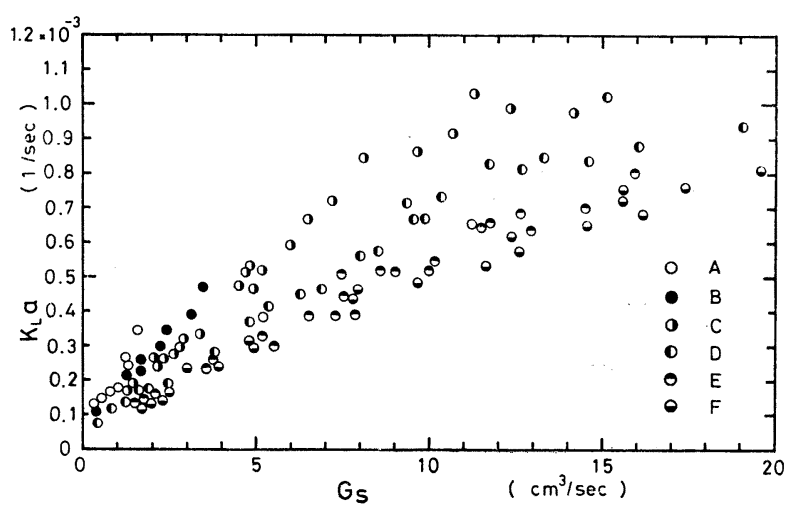

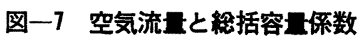




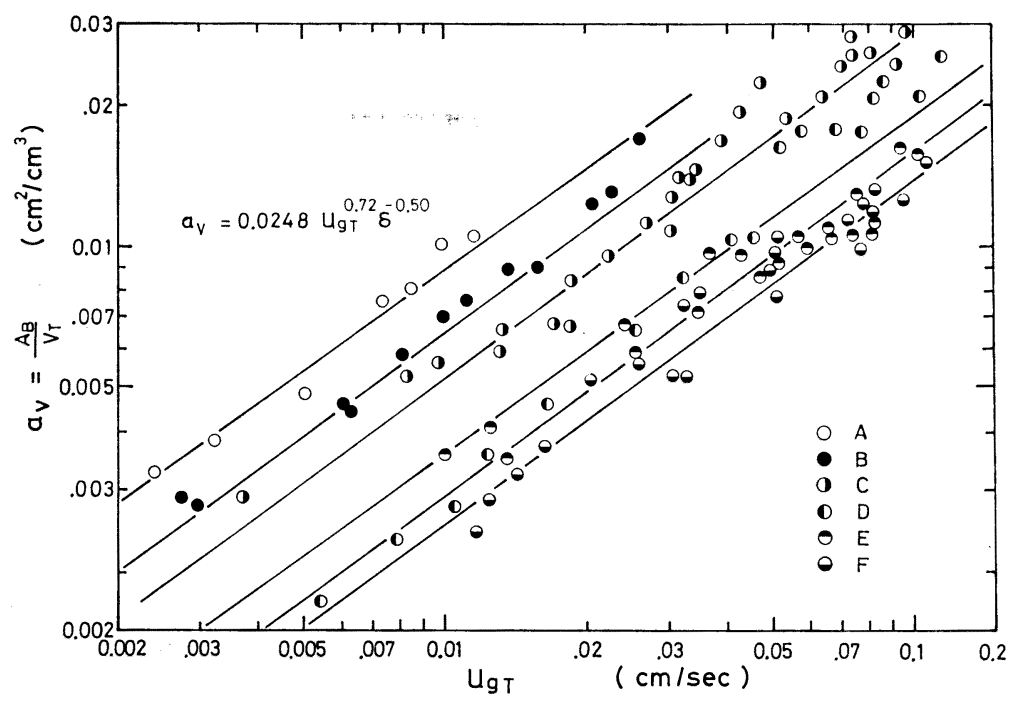

図一8 空塔速度と総括容量係数
となり，

$K_{L} a \cdot V_{T}=k_{L} \cdot A_{B}+k_{L e} \cdot A_{e}$

を得る.ここに， $A_{B}$ は槽内を 上昇している気泡の気液接触界 面面積, $A_{e}$ は端効果の代表界 面面積, $k_{L}$ は気泡の液境膜係 数, $k_{L e}$ は端効果による酸素移 動の液境膜係数である. 気泡の 気液接触界面面積 $A_{B}$ は, カラ 厶内に存在する気泡の平均表面 積 $\bar{s}_{B}$, 平均体積 $\bar{v}_{B}$, 平均上昇 速度 $\bar{u}_{b}$ と空気流量 $G_{s}$ および 水哚 $z_{H}$ の関係方，

$$
A_{B}=\frac{\bar{s}_{B} \cdot G_{s} \cdot z_{H}}{\bar{v}_{B} \cdot \bar{u}_{b}}
$$

として求めることができるが，
べている. また, Beek ら ${ }^{19)}$ や, Calderbank $ら^{20)}$ は, 気泡の発生時には特に大きな物質移動は起こ らない, と報告している.

このように，端効果の影響についての評価は一 般に小さいが，河川や湖沼等における自由水面か らの酸素の移動現象, 寸なわち再曝気現象は大き な意味をもっていることから，エアレーション時 における自由水面からの酸素の移動, さらに, 気泡の生 成・破裂時における酸素の移動等を端効果として考える とき, 衛生工学的にこれを無視することはできないであ ろう.

カラム内が乱流状態で, 位置による酸素の濃度分布は なく, 槽内全体にわたって均一な濃度であり, 酸素の全 移動が, 気泡の上昇時および端効果の 2 つの移動からな っていると考えると，

$$
\begin{aligned}
\frac{d c}{d t} & =K_{L} a\left(c_{s}-c\right) \\
& =k_{L} \cdot \frac{A_{B}}{V_{T}}\left(c_{s}-c\right)+k_{L e} \cdot \frac{A_{e}}{V_{T}} \cdot\left(c_{s}-c\right) \cdot \cdot
\end{aligned}
$$

\begin{tabular}{|c|c|c|c|c|}
\hline & A & $\mathrm{C}$ & $\mathrm{D}$ & $\mathrm{E}$ \\
\hline 気泡発生孔径 $\delta$ & 0.010 & 0.031 & 0.060 & 0.089 \\
\hline 水 $\quad$ 深 $z_{H} \quad(\mathrm{~cm})$ & $80 \sim 40$ & $95 \sim 60$ & $95 \sim 40$ & $95 \sim 40$ \\
\hline 空気流量 $G_{s}\left(\mathrm{~cm}^{3} / \mathrm{sec}\right)$ & $0.34 \sim 0.45$ & $0.56 \sim 0.67$ & $0.82 \sim 0.92$ & $0.90 \sim 1.15$ \\
\hline$W_{e} \cdot F_{r}^{-1 / 2} \quad(-)$ & $1.86 \sim 2.48$ & $1.75 \sim 2.09$ & $1.84 \sim 2.06$ & $1.67 \sim 2.13$ \\
\hline 発生気泡径 $D_{v}$ & $0.22 \sim 0.26$ & $0.38 \sim 0.42$ & $0.60 \sim 0.64$ & $0.65 \sim 0.70$ \\
\hline 気泡上昇速度 $\boldsymbol{u}_{b} \quad(\mathrm{sm} / \mathrm{sec})$ & $15.3 \sim 19.3$ & $17.0 \sim 28.2$ & $20.2 \sim 26.7$ & $22.1 \sim 32.9$ \\
\hline
\end{tabular}

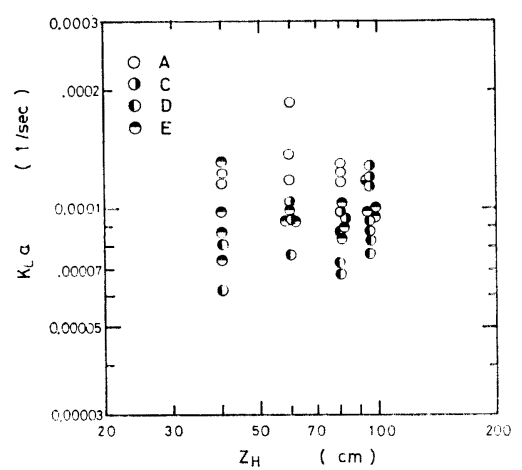

図一9. 水深変化と総括容量係数
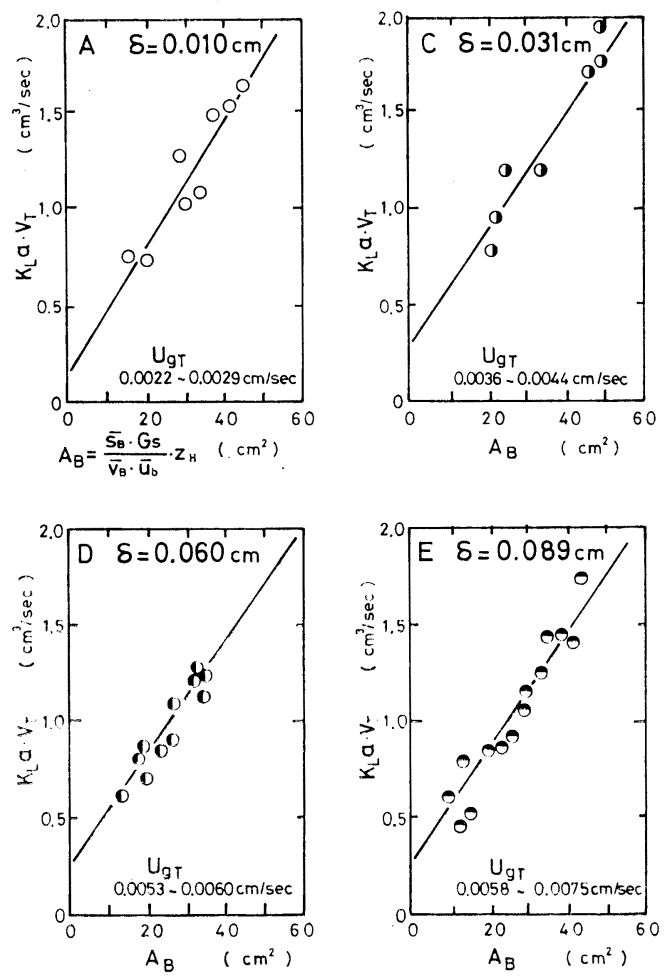
3. (2) で示しているように, 直接写真撮影によって, 長 径 $D_{a}$, 短径 $D_{b}$ より回転棈円体としての表面積 $s_{B}$ と 個数号，

$$
A_{B}=\sum n_{B} \cdot s_{B}
$$

としても求めることができ, ここでは後者の直接法によ って $A_{B}$ を求めた.

表一3 に, 端効果を求めるために行った実験条件を示 している.

図一9 は, 端彸果を求めるために, 水深 $z_{H}$ を変化さ せた場合の総括容量係数 $K_{L} a$ を示したものであるが, $K_{L} a$ 自体の変化は顕著ではない.

図一10 は, 端効果としての酸素移動を求めるために 水深 $z_{H}$ を変化させ, 式 (20) と式 (21) または式 (22) の考え方に従って, 気泡の界面面積が水深によって変化 することを利用し, 気液接触界面面積 $A_{B}$ に対して総括 移動係数容量積 $K_{L} a \cdot V_{T}$ を点綴したものである注4). 空 気流量一定のもと, すなわち, 気泡生成速度および気泡 の破裂・消滅速度を一定に保った状態において, 気泡の 自由上昇距離 $z_{H}$ を変化させた場合の $K_{L} a \cdot V_{T}$ の実測 值と式 (21) から, 水媣 $\approx H$ を0の極限とした場合,す なわち, 気泡は生成されると同時に自由水面にただちに 到達して破裂・消滅し, 気泡上昇時の界面面積がない $A_{B} \fallingdotseq 0$ に外插して, 端効果の大きさ $k_{L e} \cdot A_{e}$ として $0.172 \sim 0.275 \mathrm{~cm}^{3} / \mathrm{sec}$ を得た.

一方, 宮内 ${ }^{23)}$ らは, 擋拌槽や気泡塔に打ける自由表面 での液側物質移動係数について,

$$
k_{L e}=0.5\left(\frac{\varepsilon}{\nu}\right)^{1 / 4} \cdot \mathscr{D}_{L^{1 / 2}}
$$

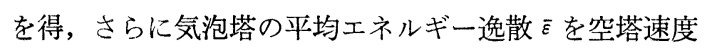
の関数として次式を示し，

$$
\bar{\varepsilon}=g \cdot u_{g} T
$$

また, 自由表面近傍のエネルギー逸散 $\varepsilon$ と平均エネル ギー逸散 $\bar{\varepsilon}$ の関係について実測值より,

$$
\varepsilon \fallingdotseq 0.06 \bar{\varepsilon}
$$

と表わすことができることを報告している.

式 (23)，(24）および（25）より，自由表面での液境 膜係数 $k_{L e}$ は,

$$
\begin{aligned}
k_{L e}=0.5\left(\frac{\varepsilon}{\nu}\right)^{1 / 4} & \cdot \mathscr{D}_{L^{1 / 2}}=0.247 \cdot\left(\frac{g \cdot u_{g T}}{\nu}\right)^{1 / 4} \\
& \cdot \mathscr{D}_{L^{1 / 2}} \ldots \ldots \ldots \ldots \ldots \ldots \ldots \ldots \ldots \ldots \ldots \ldots \ldots
\end{aligned}
$$

で示され, 空塔速度 $u_{g T}$ の関数として求めることがで きる.

これより，本実験における端効果を含めた自由水面か

注 4) 気泡の気液接触界面面積と水深について

気泡は発生後数 $\mathrm{cm}$ で終端速度に到達し, かつ, 空気流量が 一定であることから，既報に示したように， $s_{B}, v_{B}, u_{b}$ はほぼ 一定值となる。したがって, 気泡の気液接触界面面積 $A_{B}$ は水 深 $z_{H}$ のみの関数となる.
らの酸素移動に関する液境膜係数 $k_{L e}$ は, 0.00456 $0.00596 \mathrm{~cm} / \mathrm{sec}$ として求めることができ, 前述の $k_{L e}$. $A_{e}=0.172 \sim 0.275 \mathrm{~cm}^{3} / \mathrm{sec}$ の結果と対応することによっ て, 端効果代表界面面積 $A_{e}$ は $38 \sim 53 \mathrm{~cm}^{2}$ となる. この 端効果代表界面面積は, 観察時の自由水面における気泡 の分散・消滅範囲とほぼ一致する．すなわち，宮内ら ${ }^{23)}$ の自由表面での物質移動を検討した場合の湧き出し面に 対応するものと考えることができよう．このように，式 （20）中に抢ける端効果代表界面面積 $A_{e}$ は，気泡の生 成時・破裂時および自由水面からの酸素の移動を含めた 端効果による酸素移動時の界面面積の総和であるが，生 成時・破裂時の界面面積を含めて, 涌き出し面として上 述の $A_{e}$ の值の平均值 $45 \mathrm{~cm}^{2}$ 程度の大きさであると推 定される.

また，図一10に見られるごとく,端効果としての酸素 移動は, 空塔速度の大きさにもよるが, 水深が小さくな って, 気泡上昇時の気液接触界面面積が小さくなるほ ど, 全体の酸素移動に対して占める割合は大きくなり, これを無視できないことがわかる.柏谷ら ${ }^{21}$ は，水深 3.6 $\mathrm{m}$ の大型エアレーションタンクを用いて実験を行い，河 川の再曝気の考え方を導入して結果を整理し，自由水面 からの酸素の移動は，全体の移動の $1.5 \sim 5 \%$ であると 報告している.

\section{（5）気泡の液境膜係数 $k_{L}$ について}

3. (3) で，筆者らは気泡エアレーションカラムにおけ る総括容量係数 $K_{L} a$ を求めた. しかしながら,この総 括容量係数 $K_{L} a$ の中には, 式 (19) に示されるように 端効果による酸素移動が含まれている.端効果による酸 素移動は, 気泡生成時や気泡破裂時および自由水面から の移動であり, 生成・破裂時の複雑な機構・水面での乱 れ強さ等が影響すると考えられる.一方，3.(4) で考察 したように, 端効果として考えられる移動に関して, 自 由水面での酸素移動に代表させた液境膜係数 $k_{L e}$ を, 自 由水面での乱れエネルギーを媒介として空塔速度 $u_{g T}$ で示すことができること，また，その代表界面面積とし ては，涌き出し面と考えられる自由水面での気泡の分 散・破裂範囲をほぼ用いることができることなどから， カラム内での総括容量係数 $K_{L} a$ より端効果を分離し, さらに, 式 (13) を用いることにより, 気泡上昇時の液 境膜係数 $k_{L}$ を分離し, 考察してみる.

一般に, 酸素ガスのような難溶解性ガスの場合, ガス 境膜俰数 $k_{g}$ は無視可能であり, このようなときには, 液境膜係数 $k_{L}$ が支配的となって,

$$
K_{L} \fallingdotseq k_{L}
$$

とみなすことができ, 端効果による酸素移動を除いた総 括容量係数 $K_{L} a$ と液境膜係数 $k_{L}$ との間には次式が成 


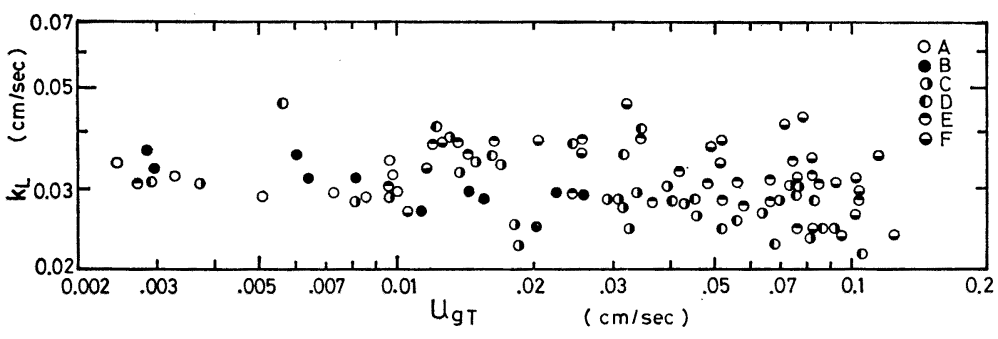

図一11空塔速度と液境膜係数

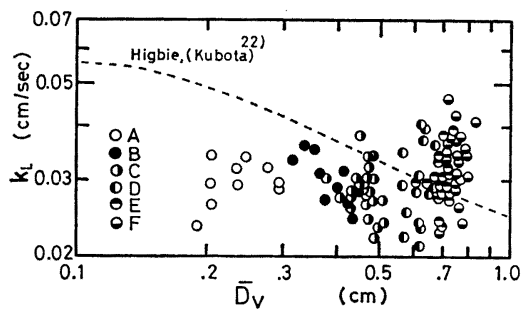

図一12 気泡径 $\boldsymbol{D}_{v}$ と液境膜係数

立する。

$K_{L} a=k_{L} \cdot a_{V}$

また, 総括容量係数 $K_{L} a$ および気泡の気液接触界面 面積 $a_{V}$ はそれぞれ，3.(3)，(2) のように得られてい ることから端効果による酸素移動を考慮して, 総括容量 係数 $K_{L} a$ から気泡の液境膜係数 $k_{L}$ を分離して点緅し たのが 図一11 であり, 一方, 気泡径 $D_{v}$ に対して点淑 したのが図一12 である. 只木ら ${ }^{16)}$ は, 気泡発生孔径 $=0.04 \sim 0.08 \mathrm{~cm}$ の多孔板を用いて炭酸ガスの放散実験 から気泡塔の容量係数を求め，また写真撮影法によって 気泡群の比接触面積を算定し, 容量係数から物質移動係 数 $k_{L}$ を分離し, $k_{L}$ は発生孔径 $\delta$ にはあり影響され ないこと, 空塔速度 $u_{g T}$ が大きくなるにつれて $K_{L} a$ が 大きくなるのは，主として界面面積 $a$ の増加のためで あって, $k_{L}$ 自身はあまり変化しないことなどを指摘し ている.

このように, 空塔速度 $u_{g} T$ や気泡径 $D_{v}$ によらず, 液境膜係数 $k_{L}$ がほぼ $0.02 \sim 0.04 \mathrm{~cm} / \mathrm{sec}$ と一定の值が 示されるのは, 空塔速度が小さいために, 気泡のホール ドアップが小さく，カラム内において気泡は，相互に干 涉し合いながらも, 分裂・合体現象はなく, 個々独立し て上昇運動していること, また, 気泡径が $0.2 \sim 0.9 \mathrm{~cm}$ の範囲であって，既報9 のように，気泡のレイノルズ数 や抵抗係数で示される気泡の挙動が固体球に近い気泡と はかなりかけ離れたものであって，常に界面は乱れてい て，界面を通しての酸素ガスの液への浸透が，ほぼ一定 の大きさで行われていることなどの理由が考えられよ う. また, 装置的にも, 市販の蒸留水では界面の污染を 防ぎ切れなかったことも一つの理由であろら。

次に, 液境膜係数 $k_{L}$ に関係する因子として, 気泡径
$\bar{D}_{v}$, 上昇速度 $\bar{u}_{b}$, 酸素の水中で の抎散係数 $\mathscr{D}_{L}$ をとりあげ,

$$
k_{L}=f\left(\bar{D}_{v}, \bar{u}_{b}, \mathscr{D}_{L}\right)
$$

として次元解析を行うと

$$
\frac{k_{L}}{\bar{u}_{b}}=\alpha \cdot\left(\frac{\bar{D}_{v} \cdot \bar{u}_{b}}{\mathscr{D}_{L}}\right)^{\beta}
$$

を得, 液境膜係数の気泡上昇速度 に対する比 $k_{L} / \bar{u}_{b}$ がペクレ数の関 数として示すことができる.

図一13 は，式 (30) に基づいて実測值を整理して点败 したものであり，ペクレ数が大きくなるにつれて $k_{L} / \bar{u}_{b}$ が小さくなっている. 一方, 図一12 中の破線は, Higbie の浸透説モデル ${ }^{21)}$ に基づく液境膜係数,

$$
k_{L}=2 \sqrt{\frac{\mathscr{D}_{L} \cdot u_{B}}{\pi \cdot D_{v}}}
$$

を久保田ら ${ }^{22)}$ の実験結果より求めて示したものであり, 図一13 中の破線は，これをペクレ数の関数として示し たものである.

本研究においては，粘性項の変化を扱っていないた め, シャーウッド数やシュミット数およびレイノルズ数 などの無次元群として整理し得なかったが, ペクレ数が 流れの状態による乱流昖散および流体の性質を包括した 形であることより，気泡群からの酸素移動を支配すると 考えられる液境膜係数を整理した.

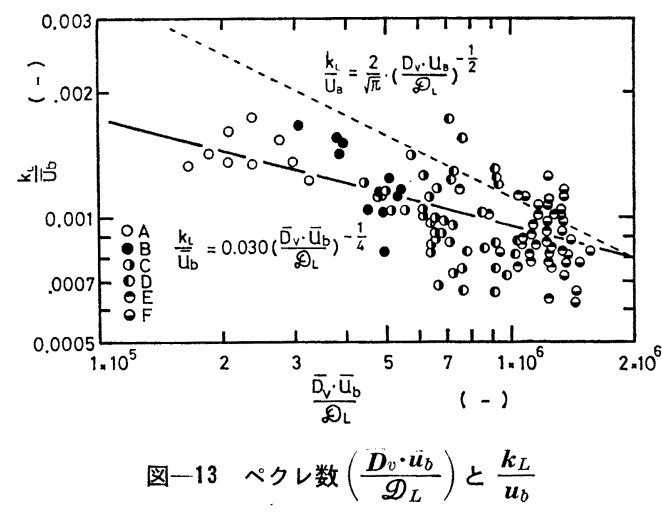

\section{4. ま と め}

単一孔を通して水中に発生する気泡群からの酸素移動 について実験を行い，次のような諸点が明らかとなっ た.

（1）槽の単位体積当りの気泡の個数や大きさを写真 から測定し，この結果と空塔速度の関係から，気泡流動 層の範囲における気泡のホールドアップを推定できる.

（2）気泡群の平均上昇速度を空塔速度から推定する ことができる。

（3）気泡の気液接触界面自積 $a_{V}$ は空塔速度が大き 
くなるほど, また, 気泡発生孔径が小さくなって気泡径 が小さいほど，大きくなる.

(4) 総括容量係数 $K_{L} a$ は, 空塔速度が大きくなる ほど, また, 気泡発生孔径が小さくなるほど, 大きくな るが,これはガスホールドアップが大きくなって気液接 触界面面積が大きくなることによるものであろう．

（5）端効果による酸素移動を自由水面からの酸素移 動に代表させることによって, 液境膜係数 $k_{L e}$ を推定 L, $0.004 \sim 0.006 \mathrm{~cm} / \mathrm{sec}$ の值を得た.

(6) 端効果による酸素の移動は, 空塔速度によって も異なるが，水哚が小さくなるほど，全体の酸素移動に 対して占める割合が大きくなる.

（7）気泡からの酸素移動に関する液境膜係数 $k_{L}$ は, 平均気泡径が $0.2 \sim 0.9 \mathrm{~cm}$ の範囲では，ほぼ $0.02 \sim$ $0.04 \mathrm{~cm} / \mathrm{sec}$ である。

（8）気泡の液境膜係数を気泡上昇速度およびペクレ 数によって整理した.

実際のエアレーションタンクにおいては, 多孔盤や多 孔管などの散気装置を用いて活性污泥混合液に酸素の供 給がなされている. 現時点において本研究の結果を直接 実処理に結びつけることはできないが，今後さらに物性 条件や装置条件に対応する実験データの蓄積を行うこと により，実設計や実操作に演繹することが可能とな子 う.ことに，気泡の液境膜係数や端効果に上る酸素移動 の把握は, 気泡群による酸素供給といら観点から, 多く の因子が複雑に作用するエアレーションの内部機構を解 明していくうえで，一のの示唆となるものと考えられ る.

終わりに, 本研究をすすめるにあたり, 適切なご助言 を賜った東北大学二学部化学工学科 只木慎力教授, 宝 沢光紀助教授，ならびに実験にご協力いただいた仙台市 大滝羓哃可氏，菅出秀穂氏，木更津工業高等専門学校 高 橋克夫講師に感謝の意を表します.また, 計算にあたっ ては, 東北大学大型計算機 NEAC-2200 モデル 500 を 使用したことを記す.

\section{使用記号}

$A_{T}$ : カラム (タンク) 断面積

$\left(\mathrm{cm}^{2}\right)$

$A_{B}:$ 気泡の気液接触界面面積

$\left(\mathrm{cm}^{2}\right)$

$a_{V}$ : 単位宫積当りの気泡の気液接触

界面泊積 $\left(=\frac{A_{B}}{V_{T}}\right)$

$\left(\mathrm{cm}^{2} / \mathrm{cm}^{3}\right)$

$A_{\epsilon} \quad$ : 端効果における代表接触界面面積

$\left(\mathrm{cm}^{2}\right)$

c : 水中の酸素濃度

$(\mathrm{mg} / \mathrm{l})$

is : 水中の飽和酸素濃度

$(\mathrm{mg} / \mathrm{l})$

$c_{u^{\prime} s}$ : 大気庄に打汀る水中の飽和酸素濃度 $(\mathrm{mg} / l)$
$D_{a}$ : 気泡の長径

(cm)

$D_{b}$ : 気泡の短径

(cm)

$D_{v}$ : 球体積相当気泡值径

$\bar{D}_{v}$ : 球体積相当平均気泡直径

(cm)

$D_{v s}$ : 体面積相当気泡直径

(cm)

$\mathscr{D}_{L}$ : 酸素ガスの水中桩散係数

$\left(\mathrm{cm}^{2} / \mathrm{sec}\right)$

$F_{r}$ : フルード数 $\left(=u_{G}{ }^{2} / g \cdot \delta\right)$

$G_{s}$ : 空気流量

$\left(\mathrm{cm}^{3} / \mathrm{sec}\right)$

$g$ : 重力加速度 $\left(\mathrm{cm} / \mathrm{sec}^{2}\right)$

$h_{\varepsilon}:$ 気泡のホールドアップ

$K_{L} \quad$ : 物質移動総括係数

$(\mathrm{cm} / \mathrm{sec})$

$K_{L} a$ : 総括容量係数

$(1 / \mathrm{sec})$

$k_{g}:$ : ス境膜係数 (ガス側物質移動係数)

$(\mathrm{cm} / \mathrm{sec})$

$k_{L} \quad$ : 液境膜係数（液側物質移動係数） $(\mathrm{cm} / \mathrm{sec}$ )

$k_{L e} \quad$ : 端効果における液境膜係数 $\quad(\mathrm{cm} / \mathrm{sec})$

$k_{s} \quad$ : 表面積形状係数 （一)

$k_{v} \quad$ : 体積形状係数 （一)

$N_{B}$ ：カラム内に存在する気泡総個数 （個）

$\mathrm{N}_{\mathrm{O}_{2}}$ : 酸素吸収速度 $\left(\mathrm{mgO}_{2} / \mathrm{sec}\right)$

$N_{W}$ : ガス流速因子数 $\left(=W_{e} \cdot F_{r^{-1 / 2}}\right) \quad(-)$

$n_{B}$ : カラム内における単位容積中の 気泡個数

(個 $/ \mathrm{cm}^{3}$ )

$n_{B \tau} \quad$ ：単位時閒当りの気泡発生個数（個 $/ \mathrm{sec}$ )

$P$ : 庄少

$R_{e}:$ レイノルズ数 $\left(=D_{v} \cdot u_{b} / \nu\right)$

(mAq)

$s_{c} \quad:$ シュミット数 $\left(=\nu / \mathscr{D}_{L}\right)$

$(-)$

$(-)$

$s_{h} \quad:$ シャーウッド数 $\left(=k_{L} \cdot D_{v} / \mathscr{D}_{L}\right)$

$s_{B} \quad:$ 気泡の表面積

$(-)$

$\left(\mathrm{cm}^{2}\right)$

$\bar{s}_{B} \quad:$ 気泡の平均表面積

$\left(\mathrm{cm}^{2}\right)$

$u_{B}$ : 単一気泡の静止水中での上昇速度 $(\mathrm{cm} / \mathrm{sec})$

$u_{b} \quad$ : 気泡の水中みかけ上昇速度 $\quad(\mathrm{cm} / \mathrm{sec})$

$\bar{u}_{b} \quad$ : 気泡の水中及かけ平均上昇速度 $(\mathrm{cm} / \mathrm{sec})$

$u_{G} \quad$ : 気泡発生孔における空気流速 $\quad(\mathrm{cm} / \mathrm{sec})$

$u_{g T}:$ 空塔速度

$(\mathrm{cm} / \mathrm{sec})$

$V_{T} \quad$ : カラム容積

$V_{B} \quad:$ カラム内の総気泡体積

$\left(\mathrm{cm}^{3}\right)$

$\left(\mathrm{cm}^{3}\right)$

$v_{B} \quad:$ 気泡の体積

$\left(\mathrm{cm}^{3}\right)$

$v_{B} \quad$ : 気泡の平均体積

$\left(\mathrm{cm}^{3}\right)$

$W_{e}:$ : ウバー数 $\left(=\rho_{L} \cdot u_{G}{ }^{2} \cdot \delta / \sigma\right) \quad$ (一)

$\mathrm{WO}_{2}$ : 酸素吸収量

$\left(\mathrm{mgO}_{2}\right)$

$\approx \quad$ : 測定 (撮影) した水樑 $\quad(\mathrm{cm})$

$\check{z}_{H} \quad$ : 力ラムの水深 $\quad(\mathrm{cm})$

$\alpha \quad$ : 実験定数 (一)

B : 実験定数 （一)

o : 気泡発生孔径 (cm)

$\varepsilon \quad:$ エネルギー逸散 $\quad\left(\mathrm{cm}^{2} / \mathrm{sec}^{3}\right)$ 
$\begin{array}{llr}\bar{\varepsilon} & : \text { 平均エネルギー逸散 } & \left(\mathrm{cm}^{2} / \mathrm{sec}^{3}\right) \\ \nu & : \text { 水の動粘性係数 } & \left(\mathrm{cm}^{2} / \mathrm{sec}\right) \\ \pi & : \text { 円周率 } & (\text { 一) } \\ \rho_{L} & : \text { 水の密度 } & \left(\mathrm{g} / \mathrm{cm}^{3}\right) \\ \rho_{G} & : \text { 空気の密度 } & \left(\mathrm{g} / \mathrm{cm}^{3}\right) \\ \sigma & : \text { 水の表面張力 } & (\mathrm{dyn} / \mathrm{cm}) \\ \tau & : \text { 時間 } & (\mathrm{sec}) \\ \tau_{\theta} & : \text { 気泡の滞留時間 }\left(=z_{H} / u_{b}\right) & (\mathrm{sec}) \\ \phi_{s} & : \text { 形状係数 } & (一)\end{array}$

\section{参 考 文 献}

1) King, H.R. : Mechanics of oxygen absorption in spiral flow aeration tanks. I. Derivation of formulas, Sewage and Ind. Wastes., Vol. 27, No. 8, pp. 894 $908,1955$.

2）柏谷 衛・安中徳二・及川直也：散気式エアレーション タンクの酸素移動, 第 7 回 衛生工学研究討論会講演論文 集, pp. 91 102, 1971.

3) Bewtra, J.K. and W.R. Nicholas : Oxygenation from diffused air in aeration tanks, Jour. W.P.C.F., Vol. 36, No. 10, pp. 1195 1224, 1964.

4）寺岡 初・清水 洽 - 浅野和彦・福永 念 - 久保田勝義 : 曝気装置の基礎的研究一各種散気管の曝気性能について, 水道研究所報告, Vol. 5, No. 1, pp. 12 18, 1968.

5）宗宫 功：活性污泥法の操作因子に関する基礎的研究, 京都大学学位論文, pp. 9 48, 1968.

6) Pasveer, A. : Research on activated sludge. VI. Oxygenation of water with air bubbles, Sewage and Ind. Wastes, Vol. 27, No. 10, pp. 1130 1146, 1955.

7) Banhart, E.W. : 'Transfer of oxygen in aqueous solutions, Proc. A.S.C.E., SA 3, Vol. 95, pp. 645 661, 1969.

8) Suschka, J. : Oxygenation in aeration tanks, Jour. W. P.C.F., Vol. 43, No. 1, pp. 81 92, 1971.

9）松本順一郎・ 中村玄正：単一孔から発生する気泡の性状 と分布特性について, 土木学会論文報告集, 第 260 号, pp. $75 \sim 87,1977$.

10) Oldshue, J.Y. : Aeration of Biological System Using Mixing Impellers, Biological Treatment of Sewage and Industrial Wastes, Reinhold, pp. 231 240, 1956.

11）化学工学協会: 化学工学便覧, 丸善, pp. 1 90, 1970.

12）化学工学協会編：気泡分散相によるガス吸収一気泡・液 滴工学, 日刊工業新聞社, pp. 83 108, 1969.

13) Yoshida, F. andAkita, K. : Performance of gas bubble columns, A.I.Ch. E. Jour., Vol. 11, pp. 9 13, 1965.

14）吉留 浩: 水中に㧍ける気泡群の平均上昇速度について, 化学工学, Vol. 27, No. 1, pp. 27 31, 1963.

15）小出耕造・平原照晏 - 久保田 宏: 気泡群の平均気泡径・ 上昇速度およびガスホールドアップ, 化学工学, Vol. 30 , No. 8, pp. $712 \sim 718,1966$.

16）只木楨力・前田四郎：気泡塔に抢ける水よりの炭酸ガス の放散について, 化学工学, Vol. 27, No. 11, pp. 808〜 814, 1963.

17) Eckenfelder, W.W. and D.J. O'Connor(岩井重久訳) : 廃水の生物学的処理, コロナ社, pp. 88 89, 1970.

18) Johnson, A.I. and C.W. Bowman : Canad. Jour. Chem. Eng., Vol. 36, p. 253, 1958.

19) Beek, W.J. and H. Kramers : Mass transfer with a change in interfacial area, Chem. Eng. Sci., Vol. 16, pp. 909 921, 1962.

20) Calderbank, P.H. and A.C. Lochiel : Mass transfer coefficients, velocities and shapes of carbon dioxide bubbles in free rise through distilled water, Chem. Eng. Sci., Vol. 19, pp. 485〜503, 1964.

21）たとえば, Danckwerts, P.V. : Significance of LiquidFilm Coefficients in Gas Absorption, Ind. Eng. Chem., Vol. 43, No. 6, pp. 1460 1465, 1951.

22）久保田誠・明畠滈司・白井隆：低粘度液中心打沙る 单一気泡の挙動について, 化学:工学, Vol. 31, No. 11, pp. 1074 1080, 1967.

23）片岡 広・宮内照勝：乱流域の擋拌槽自由表面における 液側物質移動係数におよぼす物性および乱れの影響, 化 学工学, Vol. 36, No. 8, pp. 888 896, 1972.

(1976.8.2 - 受付) 